\title{
Psychoemotional state of patients 60+ years old with chronic cerebrovascular insufficiency relocating with their family from the far north
}

\author{
LIUDMILA G. KLIMATCKAIA ${ }^{1, \mathrm{c}-\mathrm{G}}$, OLGA I. ZAITSEVA ${ }^{2, \mathrm{c}-\mathrm{G}}$
}

${ }^{1}$ Department of Social Pedagogy and Social Work, Krasnoyarsk Pedagogical University, Krasnoyarsk, Russia ${ }^{2}$ Science-Research Institute of Medical Problems of the North, Russian Academy of Medical Sciences,

Siberian Branch, Krasnoyarsk, Russia

A - Study Design, B - Data Collection, C - Statistical Analysis, D - Data Interpretation, E - Manuscript Preparation, $\mathbf{F}$ - Literature Search, $\mathbf{G}$ - Funds Collection

Summary Background. In the Soviet period, people came to work in the Far North of the Krasnoyarsk Territory. Now they are retired. Remaining retired in the North is not economically feasible. Resettlement of unemployed elderly people to the more favorable southern climatic zones of central Siberia is connected with a demographic situation. For families 60+ years old, the "From the Extreme North to the South" program was created. The article presents the results of studies on the psychoemotional state of migrants $60+$ years old

Objectives. To study the psychoemotional state of patients $60+$ years old with chronic cerebrovascular insufficiency when adapting from the North to the South.

Material and methods. 98 migrants from the North to the South were examined. These were people with a chronic insufficiency of brain blood circulation at the age of $60+$ years old. Patients were tested utilizing the G. Eysenck and A.S. Zigmond, R.P. Snaith. Hospital Anxiety and Depression Scale.

Results. Various types of personality were revealed: extroverts $-60.2 \%$ (59 people), introverts $-39.8 \%$ (39 people). Emotionally stable migrants $60+$ years old $-25.5 \%$ (28 people). Emotionally unstable $-74.5 \%$ ( 70 people). The sociability combination with impulsiveness was characteristic with a high level of emotional instability ( $17.27 \pm 0.26$ points). At very high level (19.5 \pm 0.31 points), low self-esteem and an emotional block were revealed.

Conclusions. 1. Emotionally stable migrants $60+$ years old readapt fairly. 2. High and very high levels of neuroticism demonstrate the formation of anxiety disorders and restriction of adaptive opportunities in migrants $60+$ years old. Treatment and prophylactic actions are provided to them.

Key words: Original Input (length: 6766), potential of elderly migrants, social networks of elderly migrants: on the basis of familial and intra-ethnic support.

Klimatckaia LG, Zaitseva OI. Psychoemotional state of patients 60+ years old with chronic cerebrovascular insufficiency relocating with their family from the far north. Fam Med Prim Care Rev 2016; 18(4): 429-431, doi: 10.5114/fmpcr.2016.63696.

\section{Background}

In the documents of the European regional bureau of the World Health Organization (WHO), the age from 60 to 74 years is considered as elderly; $75-89$ years - senile; 90 years and older - the longevity period. In foreign literature, the distinction of "young elderly" is 65-74 years, "old" - 75-84 years, and "very old" - 85 years [1].

During the Soviet period, people came to work in the Far North of the Krasnoyarsk Territory. Now they are retired. Remaining retired in the North is not economically feasible. Resettlement of unemployed elderly people from northern areas of the Krasnoyarsk Territory to the more favorable southern climatic zones of central Siberia is connected with a demographic situation. During resettlement, the elderly migrants who have lived in the north up to 20 years have problems of social and economic arrangement and a complex of the medical and psychological problems connected with the readaptation to climatic conditions [2-4]. The problem of the adaptation of elderly people draws the attention not only of clinical physicians [5], but also of representatives of fundamental fields [6]. Researches gain complex character and exist on adjacent fields of ecology, physiology, psychology, medicine, economiy [7-9].

The Collins English Dictionary (2014) gives the definition of readaptation or renewed adaptation as "a process or example of adapting something again or the state of being adapted again", as the adaptation of an individual to new conditions of an earlier habitual environment, in view of a long absence from this region.

In the works of many authors, it is noted that people of various ages react rather emotionally to changes in their life $[10,11]$. The psychoemotional state is fundamental in life $[12,13]$. The data available in this field is limited and concerns only one of the parties of this problem connected with the characteristic of the state of health of the person during adaptation to the conditions of other latitudes $[1,14]$. This statement has also influenced the choice of the direction of our research.

\section{Objectives}

To study the psychoemotional state of patients $60+$ years old with chronic cerebrovascular insufficiency in readaptation. 


\section{Material and methods}

Diagnostics were carried out among 98 elderly people, migrants from the North to the South, from the age of 60-74 years (30 men and 68 women), with clinical signs of chronic cerebrovascular insufficiency. The diagnosis has been verified. The psychoemotional condition has been estimated on G. Eysenck [15] with testing on Hospital Anxiety and Depression Scale (HADS) developed by A.S. Zigmund and R.P. Snaith especially for sick people [16].

Patients with chronic cerebrovascular insufficiency of $3 d$ type, patients with diabetes, anemia, liver and renal failure, dysfunction of the thyroid gland, as well as patients abusing alcohol and taking medication for Parkinson's disease were excluded from the research.

The analysis of data was carried out with use of a statistical package of the program STATISTICA, ver. 6.0 (StatSoft Inc. USA). Statistical analysis of the obtained data was carried out utilizing the nonparametric method. The statistical importance of distinctions of qualitative signs was estimated by means of criterion $\chi^{2}$ with the amendment of Yeats. The results of research of qualitative signs are presented in the form of absolute and relative percentage, with a confidence interval of $95 \%$. The results were considered statistically significant at a significance value of $p<0.05$.

\section{Results}

Indicators of the psychoemotional state of patients 60+ years old with chronic cerebrovascular insufficiency in readaptation are presented in Table 1.

Inspection of the psychoemotional state utilizing the G. Eysenck Scale [15] has revealed moderately expressed psychological types of introversion and extraversion, irrespective of gender. All examined migrants had a moderated range of an extraversion (14-15 points). Among patients 60+ years old, these types of personality were found: extroverts $-60.2 \%$ (59 people); introverts $-39.8 \%$ (39 people); $p<0.01$.

Emotional stability was registered in $25.5 \%$ of the examined elderly people with chronic cerebrovascular insufficiency. The level of neuroticism was in the range of average emotional stability (11-14 points). The frequency of emotional instability on G. Eysenck "neuroticism-emotional stability" [15] was revealed in $74.5 \%$ cases (70 people); $p<0.001$.

The level of emotional pressure was mainly within the range of high emotional instability (17-18 points). Gender distinctions in the frequency of emotional instability occurrence were not found. The combination of sociability with hypererethism, importunity and impulsiveness was charac- teristic for elderly migrants with a high level of neuroticism (emotional instability of $17.27 \pm 0.26$ points). The growth of personal uneasiness it migrants was followed by a feeling of uncertainty, mood swings and a delay of emotions.

At very high levels of neuroticism (emotional instability of $19.5 \pm 0.31$ points), a low level of self-esteem was revealed; isolation and uneasiness was combined with an emotional block. Often these people treated themselves critically, they were not satisfied with their own behavior and level of achievements. Women gave low estimate to their personality in general and men gave low estimate to their self-confidence and ability to cope with difficulties. This corresponded to unsatisfactory readaptation $[17,18]$. A considerable prevalence of disturbing and depressive frustration in migrants considered as "old age" (65.9\% (65 people) on the HADS Scale [16]) was noted in this group. $75.5 \%$ (49 people) of those supervised had comorbidity of alarm and depression. Subclinical alarm (71.7\% (46 people)) and subclinical depression (85.5\% (55 people)) were prevalent among elderly migrants.

\section{Discussion}

Literature demonstrates that irrespective of age and gender, patients with diseases of the nervous system had changes in their emotional condition of different degree of expressiveness $[13,19,20]$. The prevalence of elderly patients with emotional instability was statistically significant in our research. The probability of success increases if there is an improvement in the quality of life as a result of resettlement $[21,22]$.

The revealed psychological types of personality in combination with the level of neuroticism cause the formation of individual adaptation and adaptive activity in immigrants from the North to the South. The features of the emotional state in migrants $60+$ years old with high and very high level of neuroticism demonstrate the formation of anxiety disorders, which is confirmed by data in literature [23]. A similar restriction of the adaptive opportunities of this category of people demands medical supervision and carrying out the treatment and prophylactic actions, including prescription of medication, which improve the psychoemotional sphere [24, 25].

\section{Conclusions}

1. Emotionally stable migrants $60+$ years old readapt fairly.

2. High and very high level of neuroticism demonstrates the formation of anxiety disorders and the restriction of adaptive opportunities in migrants $60+$ years old. Treatment and prophylactic actions are provided to them.

Table 1. Indicators of the psychoemotional state of patients $60+$ years old with chronic cerebrovascular insufficiency in readaptation, $\boldsymbol{n}=\mathbf{9 8}$

\begin{tabular}{|c|c|c|c|c|c|c|c|c|}
\hline \multirow[t]{3}{*}{ Indicators } & \multicolumn{8}{|c|}{ Psychoemotional state of patients $60+$ years old with chronic cerebrovascular insufficiency in readaptation } \\
\hline & \multicolumn{4}{|c|}{ G. Eysenck Scale [15] } & \multicolumn{4}{|c|}{ HADS Scale [16] } \\
\hline & $\begin{array}{l}\text { Extraver- } \\
\text { sion }\end{array}$ & Introversion & $\begin{array}{l}\text { Emotional } \\
\text { stability }\end{array}$ & $\begin{array}{l}\text { Emotional } \\
\text { instability }\end{array}$ & Norm & Anxiety & Norm & Depression \\
\hline $\begin{array}{l}\text { Absolute } \\
\text { number }\end{array}$ & 59 & 39 & 28 & 70 & 33 & 65 & 33 & 65 \\
\hline$\%$ & 60.2 & 39.8 & 25.5 & 74.5 & 34.1 & 65.9 & 34.1 & 65.9 \\
\hline $\begin{array}{l}95 \% \\
\text { confidence } \\
\text { interval }\end{array}$ & $\begin{array}{l}53.96- \\
-66.44\end{array}$ & $\begin{array}{l}33.38- \\
-46.21\end{array}$ & $\begin{array}{l}17.12- \\
-33.88\end{array}$ & $\begin{array}{l}69.26- \\
-79.74\end{array}$ & $\begin{array}{l}27.41- \\
-40.79\end{array}$ & $\begin{array}{l}63.98- \\
-71.82\end{array}$ & $\begin{array}{l}27.41- \\
-40.79\end{array}$ & $\begin{array}{l}63.98- \\
-71.82\end{array}$ \\
\hline$\chi^{2}$ & \multicolumn{2}{|l|}{6.89} & \multicolumn{2}{|l|}{36.0} & \multicolumn{2}{|l|}{20.9} & \multicolumn{2}{|l|}{20.9} \\
\hline$p$ & \multicolumn{2}{|l|}{$p<0.01$} & \multicolumn{2}{|l|}{$p<0.001$} & \multicolumn{2}{|l|}{$p<0.001$} & \multicolumn{2}{|l|}{$p<0.001$} \\
\hline
\end{tabular}


Source of funding: This work was funded by the authors' resources.

Conflict of interest: The authors declare no conflict of interests.

\section{References}

1. Coelho RJ, Dillon NF. Older adults with developmental disabilities: an interdisciplinary approach to grouping for service provision. Lansing, MI: Clinton-Eaton-Inham Community Mental Health Board; 1990: 10-12, 21.

2. Aghajanian NA, Baevsky RM, Berseneva AP. Problems of adaptation and teaching about health. Publishing House of People's Friendship University, 2006 [in Russian].

3. Baevsky RM, Berseneva AP. Evaluation of adaptive capabilities of the organism and the risk of diseases developing. Moscow: Medicine; 1997 [in Russian].

4. Baevsky RM. Assessment and classification of health levels from the point of view of adaptation. Vestnik AMN SSSR 1989; 8: 73-79 [in Russian].

5. Malihin FT. The quality of life due to the health of elderly persons (review). Good clinical practice $2011 ; 1: 11-18$ [in Russian].

6. Orlova GG, Lukjanova IE, Dagaeva AA, et al. Role and value of the international classification of functioning, activity and health (MKF) restrictions in the organization of the due preventive help to the population. Fundamental Research 2013; 3-2: 358-361 [in Russian].

7. Kundzewicz ZW. Zmiany klimatu, ich przyczyny i skutki - możliwości przeciwdziałania i adaptacji. Studia BAS 2012; 1(29): 9-30.

8. Kazin EM, Litvinova NA, Fedorov Al, et al. Physiological and socio-pedagogical problems of adaptation and health. Bulletin of Kemerovo State University 2013; 2(3): 6-12 [in Russian].

9. Vladimirov DG. Starshee pokolenie kak faktor ekonomicheskogo razvitiya. Sociologicheskie issledovaniya 2004; 4: 57-59.

10. Volynskaya LB. Sociokulturnaya i lichnostnaya adaptaciya cheloveka na razlichnyx stadiyax zhiznennogo cikla. Moscow: Flinta, MPSI; 2015.

11. Ilin EP, Ilin EP. Psixologiya vzroslosti. St-Petersburg: Izdatelskij dom "Piter"; 2012.

12. Nalivajko TE, Shinkaruk MV. Emocionalnoe blagopoluchie lichnosti: ot psixicheskogo zdorovya k kachestvu zhizni. Zhurnal Komsomolskogo na Amure texnicheskogo universiteta 2014; 2(3): 19.

13. Spakow A, Klimatskaya L. Ocena wybranych aspektów jakości życia kobiet w wieku 45-60 lat - wykładowców uczelni wyższych z Grodna i Krasnojarska. Probl Hig Epidemiol 2009; 4(90): 402-407.

14. Dryagina LE. Osobennosti povedeniya i vegetativnye reakcii pri adaptacii k usloviyam severa. $\vee$ materialax konferencii «Severchelovek: problemy soxraneniya zdorovya». Krasnoyarsk; 2001 May 5-6; Krasnoyarsk: NII Medproblem Severa; 2001: 157-159.

15. Rocklin T, Revelle W. The measurement of extroversion: a comparison of the Eysenck Personality Inventory and the Eysenck Personality Questionnaire. Br J Soc Psychol 1981; 4(20): 279-284.

16. Zigmond AS, Snaith RP. The hospital anxiety and depression scale. Acta Psychiatr Scand 1983; 6(67): 361-370.

17. Vejn AM. Vegetativnye rasstrojstva: klinika, lechenie, diagnostika. Moscow: Medicinskoe informacionnoe agentstvo; 2000.

18. Solominskij LV. Ispolzovanie krasnyx krovyanyx kletok dlya prizhiznennoj funkcionalnoj ocenki adrenoreceptorov. Fiziologicheskij zhurnal SSSR imeni IM Sechenova 1989; 2: 189-193.

19. Ziętalewicz U, Kulpa M, Stypuła-Ciuba B. Funkcjonowanie psychologiczne u kobiet i mężczyzn z chorobą nowotworową. Med Paliat 2014; 6(3): 145-150.

20. Leppert W, Forycka M, de Walden-Gałuszko K, et al. Ocena jakości życia u chorych na nowotwory - zalecenia dla personelu oddziałów onkologicznych i medycyny paliatywnej. Psychoonkologia 2014; 1: 17-29.

21. Lobova VA. Integrative approach in the research of personal well-being of the inhabitants of the northern regions. Vestnik of Ugristics 2013; 4(15): 82-93 [in Russian].

22. Starodubrovskaya IV. Socialnaya politika na periferijnyx territoriyax: aktualnye problemy. Moscow: Izdatelskij dom "Delo"; 2014.

23. Evert LS, Zaitseva OI, Petrova NA, et al. Indicators of the psycho-emotional status in the estimation of children's adaptation to new climato-geographical conditions of residing. Vestnik novykh meditsinskikh tekhnologiy 2013; 2(20): $64-69$ [in Russian].

24. Cuijpers P, Sijbrandij M, Koole SL, et al. The efficacy of psychotherapy and pharmacotherapy in treating depressive and anxiety disorders: a metaanalysis of direct comparisons. World Psychiatry 2013; 2(12): 137-148.

25. Cuijpers P, Sijbrandij M, Koole SL, et al. Adding psychotherapy to antidepressant medication in depression and anxiety disorders: a meta analysis. World Psychiatry 2014; 1(13): 56-67.

Tables: 1

Figures: 0

References: 25

Received: 29.06.2016

Revised: 08.06.2016

Accepted: 14.06.2016

Address for correspondence:

Professor Liudmila G. Klimatckaia, MD, PhD

Department of Social Pedagogy and Social Work

Krasnoyarsk Pedagogical University

89, Lebedeva Str.

Krasnoyarsk 660049, Russia

Tel.: +7 9135337453

E-mail: klimatskaya47@mail.ru 